Journal of Economic, Business and Accounting (COSTING)

Volume 2 Nomor 1, Juli-Desember 2018

e-ISSN : 2597-5234

https://doi.org/10.31539/costing.v2i1.376

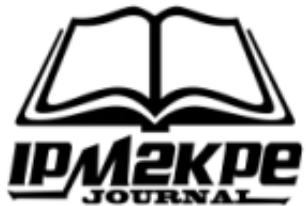

\title{
PENGARUH PRODUK DAN HARGA TERHADAP KEPUTUSAN PEMBELIAN TEPUNG BUMBU MAMASUKA
}

\author{
THE EFFECT PRODUCT AND PRICE TOWARD \\ PURCHASES DECISION MAMASUKA SPICY FLOUR
}

\author{
Dodi Agusra \\ Program Studi Sekretari Akademi Sekretari dan Manajemen Persada Bunda \\ dodi_agusra@yahoo.com
}

\begin{abstract}
The aim of this research was to determine the effect of products and prices on consumer's purchasing decisions Mamasuka spacy flour at PT Jico Agung in Pekanbaru. There were 60 consumers used as population and sample in this research. They are the consumers from shops and grocers selling Mamasuka spicy flour of PT Jico Agung in Pekanbaru. While the method used in this research was multiple linear analysis. The result showed that both products and prices affected each other in consumers' decision to buy Mamasuka spicy flour. Product and prices also affected positively consumers' purchasing decision in buying Mamasuka spicy flour at PT Jico Agung in Pekanbaru. The contribution of product and prices to consumers' purchasing decisions in buying Mamasuka was 41,6\%, while the rest is equal to 58,4\% influenced by other variables not examined in this research. PT Jico Agung was expected to improve product quality and provide competitive price as well as concern about promotion strategi used.
\end{abstract}

Keywords: Products, Prices, Purchasing Decisions

\begin{abstract}
ABSTRAK
Tujuan penelitian ini adalah untuk mengetahui pengaruh produk dan harga terhadap keputusan pembelian tepung bumbu Mamasuka oleh konsumen PT Jico Agung di Pekanbaru. Populasi dan sampel dalam penelitian ini adalah sebanyak 60 orang konsumen yang diambil dari toko atau grosir yang memiliki produk tepung bumbu mamasuka PT Jico Agung di Pekanbaru dan metode yang digunakan dalam penelitian ini adalah metode analisis linear berganda. Hasil dari penelitian ini menunjukan bahwa secara bersama-sama produk dan harga memiliki pengaruh terhadap keputusan pembelian konsumen tepung bumbu mamasuka. Secara masingmasing produk dan harga juga memiliki pengaruh yang positif terhadap keputusan pembelian konsumen tepung mamasuka PT Jico Agung di Pekanbaru. Besarnya kontribusi produk dan harga terhadap keputusan pembelian konsumen tepung bumbu mamasuka adalah sebesar 41,6\% sedangkan sisanya sebesar 58,4\% dipengaruhi oleh variabel lain yang tidak diteliti dalam penelitian ini. Melalui penelitian ini PT Jico Agung diharapkan dapat meningkatkan kualitas produk dan memberikan harga yang lebih kompetitif dan selanjutnya PT Jico Agung juga harus memperhatikan strategi promosi yang telah digunakan.
\end{abstract}

Kata kunci: Produk, Harga, Keputusan Pembelian

\section{PENDAHULUAN}

Dunia usaha sektor ritel berubah seiring dengan perubahan kebutuhan konsumen yang terus meningkat. Bagi pelaku usaha hal tersebut dapat dijadikan sebagai peluang bisnis yang menjadi dasar untuk memenuhi kebutuhan, keinginan, dan harapan konsumen sehingga tidak berpaling ke pesaing meski terjadi perubahan.

Dalam persaingan yang semakin meningkat, keberhasilan perusahaan ditentukan oleh ketepatan perusahaan dalam memanfaatkan peluang sekecil 
apapun dan mengidentifikasi kegiatan individu dalam usaha untuk mendapatkan dan menggunakan barang atau jasa dalam proses keputusan pembelian.

Perusahaan berusaha untuk memenangkan persaingan dengan memanfaatkan peluang yang ada dan berusaha dalam menerapkan strategi memasarkan usahanya untuk menguasai persaingan pasar. Perusahaan tersebut akan berusaha menggunakan strategi pemasaran dan juga pelayanannya dengan tujuan untuk mendapatkan laba yang maksimal dengan kinerja secara optimal, karena pemasaran adalah salah satu kegiatan yang dilakukan perusahaan dalam mempertahankan dari kelangsungan bisnis sekaligus dapat mengembangkan usahanya.

Krisis ekonomi menjadi bukti bahwa sektor ritel yang meliputi sektor industri perdagangan maupun jasa tetap mampu dalam mempertahankan usahanya. Hal ini mengakibatkan banyak bermunculan bisnis ritel di Indonesia yang menimbulkan terjadinya persaingan pasar. Meningkatnya pesaing bisnis di pasar akan membuat tingkat persaingan bisnis menjadi topik utama setiap perusahaan ritel, karena persaingan menjadi ketat dari tahun ke tahun di masa yang akan mendatang.

Perusahaan haruslah jeli dalam menyikapi perilaku konsumen dengan mengantisipasi terjadinya perubahan dan mempertahankan konsumen sehingga konsumen loyal terhadap produk yang dijual.

Salah satu perusahaan ritel yang ada di Pekanbaru adalah perusahaan distributor PT Jico Agung yang menjual tepung bumbu Mamasuka yang memiliki kualitas produk bagus dan harga yang terjangkau, namun tingkat penjualan tepung bumbu Mamasuka berfluktuasi setiap tahunnya dan ada yang belum sesuai dengan harapan perusahaan. hal ini disebabkan karena adanya persaingan dalam keunggulan produk dan harga dari merek perusahaan lain.

Kualitas produk dan selisih harga yang tidak terlalu jauh perbedaannya dengan kompetitor atau pesaing masih belum mampu membuat perusahaan PT Jico Agung untuk meningkatkan penjualan tepung bumbu Mamasuka pada tahun 2017. Hal ini disebabkan karena adanya persaingan harga dan keunggulan produk dari perusahaan lain seperti tepung bumbu Sajiku dan tepung bumbu Sasa.

Data penjualan tepung bumbu Mamasuka oleh PT Jico Agung tahun 2013 - 2017 dapat dilihat pada tabel 1 berikut:

\section{Tabel 1. Penjualan Tepung Bumbu Mamasuka}

\begin{tabular}{cccc}
\hline $\begin{array}{c}\text { Tahu } \\
\text { n }\end{array}$ & $\begin{array}{c}\text { Target } \\
\text { Penjualan } \\
\text { (Rp) }\end{array}$ & $\begin{array}{c}\text { Realisasi } \\
\text { Penjualan } \\
(\mathbf{R p})\end{array}$ & \% \\
\hline $\mathbf{2 0 1 3}$ & 180.000 .000 & 205.610 .000 & 114,2 \\
$\mathbf{2 0 1 4}$ & 190.000 .000 & 194.930 .000 & 102,6 \\
$\mathbf{2 0 1 5}$ & 220.000 .000 & 212.380 .000 & 96,5 \\
$\mathbf{0 2 1 6}$ & 200.000 .000 & 217.110 .000 & 108,5 \\
$\mathbf{2 0 1 7}$ & 220.000 .000 & 217.700 .000 & 98,9 \\
\hline
\end{tabular}

Sumber : PT. Jico Agung, 2018

Pada Tabel 1 diatas dapat dilihat bahwa, realisasi penjualan tepung bumbu Mamasuka dari tahun ketahun mengalami perubahan atau fluktuasi, dimana pada tahun 2013 dan 2014 penjualan melebihi dari target yang ditetapkan, sedangkan pada tahun 2015 penjualan mengalami penurunan dan tahun 2016 penjualan kembali melebihi dari target dan pada tahun 2017 penjualan tepung bumbu Mamasuka kembali mengalami penurunan atau penjualannya tidak sampai target.

Selain masalah produk, masalah selisih harga tepung bumbu Mamasuka dengan produk merek lain seperti tepung bumbu Sasa dan tepung bumbu 
Sajiku untuk lebih jelasnya dapat dilihat pada tabel 2:

\begin{tabular}{|c|c|c|c|c|}
\hline \multirow[t]{2}{*}{ No } & \multirow{2}{*}{$\begin{array}{c}\text { Produk Tepung } \\
\text { Bumbu }\end{array}$} & \multicolumn{3}{|c|}{ Harga satuan } \\
\hline & & Sasa & Sajiku & $\begin{array}{c}\text { Mama } \\
\text { Suka }\end{array}$ \\
\hline 1 & $\begin{array}{l}\text { Bakwan renceng } \\
100 \text { gram }\end{array}$ & 1.850 & 1.800 & 2.000 \\
\hline 2 & $\begin{array}{l}\text { Krispi renceng } 80 \\
\text { gram }\end{array}$ & 1.800 & 1.850 & 1.900 \\
\hline 3 & $\begin{array}{l}\text { Krispi Hot } \\
\text { renceng } 80 \text { gram }\end{array}$ & 1.900 & 1.800 & 1.900 \\
\hline 4 & $\begin{array}{l}\text { Pisang Goreng } \\
\text { renceng } 80 \text { gram }\end{array}$ & 1.850 & 1.800 & 2.000 \\
\hline 5 & $\begin{array}{l}\text { Tempe Goreng } \\
\text { renceng } 80 \text { gram }\end{array}$ & 1.800 & 1.900 & 1.950 \\
\hline
\end{tabular}

Sumber : PT.Sasa Inti , PT.Ajinomoto dan PT Jico Agung

Pada table 2 diatas dijelaskan bahwa harga antara tepung bumbu Sasa, Sajiku dan Mamasuka memiliki selisih harga Rp 150 - 200. Selain harga yang sedikit lebih mahal, kekurangan produk tepung bumbu Mamasuka adalah tidak adanya perubahan ataupun inovasi terhadap ukuran dan desain selama beberapa tahun terakhir. Hal ini berdampak pada produk tepung bumbu Mamasuka menjadi kurang diminati di pasaran.

Manajeman pemasaran adalah proses penetapan tujuan-tujuan pemasaran bagi suatu organisasi dengan mempertimbangkan sumber daya internal dan peluang pasar, perencanaan dan pelaksanaan aktivitas untuk memenuhi tujuan-tujuan tersebut, dan mengukur kemajuan ke arah pencapaiannya.

Menurut Swastha (2008) suatu sistem keseluruhan dari kegiatankegiatan bisnis yang ditujukan untuk merencanakan, menentukan harga, mempromosikan dan mendistribusikan barang dan jasa yang memuaskan kebutuhan baik kepada pembeli yang ada maupun pembeli potensial.

Menurut Assauri (2010:12) manajemen pemasaran merupakan kegiatan menganalisis, merencanakan, melaksanakan dan mengendalikan program-program yang disusun dalam pembentukan, pembangunan dan pemeliharaan keuntungan dari pertukaran/transaksi melalui sasaran pasar dengan harapan untuk mencapai tujuan organisasi (perusahaan) dalam jangka panjang.

Sedangkan menurut Hasan (2013), manajemen pemasaran adalah proses mengidentifikasi, menciptakan dan mengkomunikasikan nilai, serta memelihara hubungan yang memuaskan pelanggan untuk memaksimalkan keuntungan perusahaan.

Bicara mengenai produk, maka pilihannya akan langsung terbayang pada barang-barang yang akan dihasilkan oleh perusahaan. Bayangkan atau gambaran itu tidaklah seluruhnya benar, oleh karena itu untuk lebih jelasnya kita akan mengerti dari pengertian produk

Menurut Tjiptono (2008), produk merupakan segala sesuatu yang dapat ditawarkan produsen untuk diperhatikan, diminta, dicari, dibeli, digunakan, atau dikonsumsi pasar sebagai pemenuhan kebutuhan atau keingingan pasar yang bersangkutan.

Menurut Alma

(2011)

mendefinisikan produk sebagai Seperangkat atribut baik berwujud maupun tidak berwujud, termasuk didalamnya masalah warna, harga, nama baik pabrik, nama baik toko yang menjual (pengecer), dan pelayanan pabrik serta pelayanan pengecer, yang diterima oleh pembeli guna memuaskan keinginannya.

Beradasarkan definisi diatas dapat diketahui bahwa produk ialah suatu elemen penting yang dimiliki perusahaan untuk dijual langsung kepada ke konsumen sehingga dapat 
memenuhi kebutuhan dan keinginan konsumen.

Menurut Kotler \& Amstrong (2010), indikator produk merupakan karakteristik dari produk atau jasa yang menghasilkan kemampuan untuk memuaskan yang dinyatakan atau tersirat pada kebutuhan konsumen.

1. Kualitas produk, Merupakan salah satu alat positioning utama dalam pemasaran yang mempunyai dampak langsung pada kinerja produk serta terhubung dekat dengan nilai dan kepuasaan pelanggan. Kualitas produk memiliki 2 dimensi:

2. Performance quality. Yaitu kemampuan sebuah produk untuk melakukan fungsinya dan ketahanan produk.

3. Conformance quality. Yaitu suatu produk bebas dari kecacatan atau kerusakan dan konsisten dalam memberikan target tingkat kinerja.

4. Ukuran produk, Merupakan sarana kompetitif untuk mendiferensiasi produk perusahaan dari pesaing.

5. Desain produk, Merupakan cara lain untuk menambahkan nilai pada pelanggan. Desain yang baik tidak hanya fokus pada penampilan tetapi juga pada manfaat produk untuk dapat memenuhi kebutuhan pelanggan. Sedangkan gaya hanya menggambarkan penampilan produk, tidak benar-benar membuat kinerja produk menjadi lebih baik.

Harga merupakan salah satu unsur dari bauran pemasaran yang berperan penting dalam bauran pemasaran karena dapat memberikan pendapat bagi perusahaan, namun dapat berubah dengan cepat.

Menurut Kotler (2012) harga dapat didefenisikan secara sempit sebagai jumlah uang yang ditagihkan untuk suatu produk atau jasa. Atau dapat didefenisikan secara luas harga sebagai jumlah nilai yang ditukarkan konsumen untuk keuntungan memiliki dan menggunakan produk atau jasa yang memungkinkan perusahaan mendapatkan laba yang wajar dengan cara dibayar untuk nilai pelanggan yang diciptakannya.

Alma (2011) mendefinisikan bahwa: Harga sebagai nilai suatu barang yang dinyatakan dengan uang". Harga memiliki dua peranan utama dalam proses pengambilan keputusan para pembeli, yaitu peranan alokasi dan peranan informasi.

Sedangakan menurut Rajput, et.al (2012) harga memiliki pengaruh yang signifikan yang dirasakan kualitas ketika satu-satunya informasi ditunjukkan tersedia. Konsumen lebih suka untuk memiliki dengan harga dan kualitas dari pada aspek-aspek teknis barang tahan lama. Harga dan nilai harga dapat diukur ke efek dari biaya, markup dan sisi pembayaran (Chintagunta. 2012).

Tujuan penetapan harga yang realistis memerlukan pengawasan secara periodik untuk menentukan efektivitasnya. Tujuan penetapan harga menurut Tjiptono (2010) yaitu :

1. Tujuan berorientasi pada Laba

Tujuan ini dikenal dengan istilah maksimisasi laba. Dalam era persaingan global yang kondisinya sangat kompleks dan banyak variabel yang berpengaruh terhadap daya saing setiap perusahaan, maksimisasi laba sangat sulit untuk dicapai, karena sukar untuk dapat memperkirakan akurat jumlah penjualan yang dapat dicapai pada tingkat harga tertentu.

2. Tujuan berorientasi pada Volume Perusahaan juga ada yang menetapkan harganya berdasarkan tujuan yang berorientasi pada volume tertentu atau yang biasa dikenal dengan istilah volume 
pricing objectives. Harga ditetapkan sedemikian rupa agar dapat mencapai target volume penjualan, nilai penjualan atau pangsa pasar.

3. Tujuan berorientasi pada Citra.

Citra suatu perusahaan dapat dibentuk melalui strategi penetapan harga. Perusahaan dapat menetapkan harga tinggi untuk membentuk atau mempertahankan citra prestisius.

4. Tujuan stabilisasi Harga

Dalam pasar yang konsumennya sangat sensitif terhadap harga. Bila suatu perusahaan menurunkan harganya, maka para pesaingnya harus menurunkan pula harga mereka. Kondisi seperti ini yang mendasari terbentuknya tujuan stabilisasi harga dalam industriindustri tertentu yang produknya sangat terstandarisasi.

5. Tujuan-tujuan lainnya

Harga dapat pula ditetapkan dengan tujuan mencegah masuknya pesaing, mempertahankan loyalitas pelanggan, mendukung penjualan ulang atau menghindari campur tangan pemerintah.

Indikator yang digunakan dalam penetapan harga (Kotler, 2012):

1. Penetapan Harga. Penetapan harga, seperti halnya keputusan bauran pemasaran lainnya harus berorientasi pada pembeli. Penetapan harga yang berorientasi pada pembeli yang efektif mencakup memahami berapa besar nilai yang ditempatkan konsumen atas manfaat yang mereka terima dari produk tersebut dan menetapkan harga yang sesuai dengan nilai ini.

2. Elastisitas Harga. Seberapa responsif permintaan terhadap suatu perubahan harga. Jika permintaan hampir tidak berubah karena sedikit perubahan harga, maka permintaan tersebut tidak elastis. Jika permintaan berubah banyak, kita menyebut permintaan tersebut elastis. Semakin tidak elastis permintaan maka semakin besar peluang penjual menaikkan harga

3. Pertumbuhan Harga. Faktor lain yang mempengaruhi keputusan penetapan harga perusahaan adalah harga pesaing dan kemungkinan reaksi pesaing atas tindakan penetapan harga yang dilakukan perusahaan. Seorang konsumen cenderung membeli suatu produk atas evaluasi harga serta nilai produk pembanding sejenis lainnya.

Keputusan pembelian merupakan hal yang lazim dipertimbangkan konsumen dalam proses pemenuhan kebutuhan akan barang maupun jasa. Pada kebanyakan orang, perilaku pembelian konsumen seringkali diawali dan dipengaruhi oleh banyaknya rangsangan (stimuli) dari luar dirinya, baik berupa rangsangan pemasaran maupun rangsangan dari lingkungan yang lain.

Tahap- tahap dalam proses keputusan pembelian konsumen menurut Kotler dan Amstrong dalam Nugroho (2010) digambarkan dalam lima tahap : (1) pengenalan kebutuhan, (2) pencarian informasi, (3) evaluasi aternatif, (4) keputusan membeli, (5) prilaku pasca pembelian

Faktor-faktor yang mempengaruhi keputusan membeli berbeda-beda untuk masing-masing pembeli disamping produk yang dibeli. Menurut Swasta dan Handoko (2007) faktor-faktor tersebut adalah:

1. Lokasi penjual yang strategis

2. Pelayanan yang baik

3. Kamampuan tenaga penjualnya

4. Iklan dan promosi

5. Penggolongan barang 


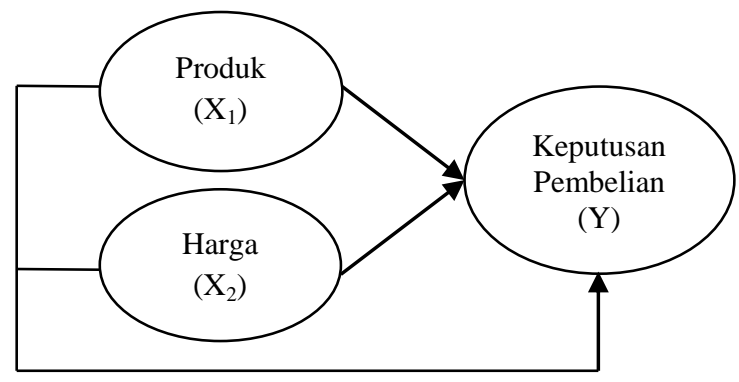

Sumber : Tjiptono (2008)

Gambar 1 Kerangka Pemikiran

Berdasarkan kerangka pemikiran diatas maka dapat dirumuskan hipotesis sebagai berikut:

1. Terdapat pengaruh produk dan harga terhadap keputusan pembelian tepung bumbu Mamasuka.

2. Terdapat pengaruh produk terhadap keputusan pembelian tepung bumbu Mamasuka

3. Terdapat pengaruh harga terhadap keputusan pembelian tepung bumbu Mamasuka.

\section{METODE PENELITIAN \\ Populasi dan Sampel}

Populasi adalah suatu kelompok yang terdiri dari objek atau subjek yang mempunyai kualitas dan karakteristik tertentu yang ditetapkan oleh peneliti untuk dipelajari dan kemudian ditarik kesimpulan (Sugiyono, 2012 : 80). Pada penelitian ini yang menjadi populasi adalah konsumen yang belanja di toko atau grosir tepung bumbu Mamasuka di Pekanbaru sebanyak 60 responden.

Menurut Sugiyono (2012 : 81), sampel merupakan bagian dari jumlah dan karakteristik yang dimiliki oleh populasi tersebut. Sampel dalam penelitian ini adalah seluruh populasi yang berjumlah 60 responden. Pengambilan sampel ini dikenal dengan istilah sensus.

\section{Jenis dan Sumber Data}

Data dalam penelitian ini harus dapat memberi gambaran secara menyeluruh tentang masalah yang di teliti. Adapun jenis dan sumber data yang digunakan adalah data primer dan data sekunder

1. Data Primer, adalah data yang diperoleh dengan mengumpulkan langsung dari lapangan atau sumber yang diamati dan dicatat untuk pertama kali. Data primer diperoleh langsung dengan membagikan kuesioner kepada konsumen pengguna tepung bumbu Mamasuka

2. Data Sekunder, adalah data yang diperoleh atau dikumpulkan dari sumber-sumber yang ada. Data ini diperoleh dari buku-buku dan sumber lainnya.

\section{Definisi Operasional Variabel Penelitian}

Jenis penelitian yang digunakan adalah penelitian deskriptif yaitu penelitian yang dilakukan dengan melakukan penggambaran atau pemaparan tentang 111variabel-variabel yang diteliti yang selanjutnya mencoba untuk menarik kesimpulan, (Sugiyono, 2011: 206).

Penelitian terdiri dari 111variabel bebas yaitu produk $\left(\mathrm{X}_{1}\right)$ dan harga $\left(\mathrm{X}_{2}\right)$, sedangkan 111variabel terikat yaitu keputusan pembelian (Y)

Menurut Sugiyono (2011: 60), variabel penelitian pada dasarnya adalah segala sesuatu yang berbentuk apa saja yang ditetapkan oleh peneliti untuk dipelajari sehingga diperoleh informasi tentang hal tersebut, kemudian ditarik kesimpulannya.

Penelitian menggunakan dua 111variabel sebagai objek penelitian,:

1. Varibel bebas

(Independent Variable), variabel yang mempengaruhi variabel tidak bebas, baik yang positif maupun negatif, sebagai variabel bebas dalam penelitian ini adalah produk $\left(\mathrm{X}_{1}\right)$ dan harga $\left(\mathrm{X}_{2}\right)$. 
2. Variabel terikat

(Dependent Variable), variabel yang menjadi akibat karena adanya variabel bebas atau 112variabel yang dipengaruhi oleh 112variabel bebasnya. Sebagai variabel terikat dalam penelitian ini adalah keputusan pembelian (Y)

Tabel 4. Variabel Penelitian dan Definisi Operasional

\begin{tabular}{|c|c|c|}
\hline Variabel & Definisi & Indikator \\
\hline $\begin{array}{c}\text { Produk } \\
\left(\mathrm{X}_{1}\right)\end{array}$ & $\begin{array}{l}\text { Merupakan salah satu } \\
\text { alat positioning utama } \\
\text { dalam pemasaran yang } \\
\text { mempunyai dampak } \\
\text { langsung pada kinerja } \\
\text { produk serta terhubung } \\
\text { dekat dengan nilai dan } \\
\text { kepuasaan pelanggan. } \\
\text { Kotler }(2010,254)\end{array}$ & $\begin{array}{l}\text { 1. Kualitas } \\
\text { produk } \\
\text { 2. Ukuran } \\
\text { produk } \\
\text { 3. Desain } \\
\text { produk } \\
\text { Kotler } \\
(2010,254)\end{array}$ \\
\hline $\begin{array}{c}\text { Harga } \\
\left(\mathbf{X}_{2}\right)\end{array}$ & $\begin{array}{lr}\text { Harga secara } & \text { luas } \\
\text { didefinisikan } & \text { sebagai } \\
\text { jumlah nilai } & \text { yang } \\
\text { ditukarkan } & \text { konsumen } \\
\text { untuk } & \text { keuntungan } \\
\text { memiliki } & \text { dan } \\
\text { menggunakan } & \text { produk } \\
\text { atau jasa } & \text { yang } \\
\text { memungkinkan } & \\
\text { perusahaan } & \\
\text { mendapatkan laba yang } \\
\text { wajar dengan } & \text { cara } \\
\text { dibayar untuk nilai } \\
\text { pelanggan } & \text { yang } \\
\text { diciptakannya. } & \\
\text { Kotler (2012:345) }\end{array}$ & $\begin{array}{l}\text { 1. Penetapan } \\
\text { Harga } \\
\text { 2. Elastisitas } \\
\text { Harga } \\
\text { 3. Pertumbuhan } \\
\text { Harga }\end{array}$ \\
\hline $\begin{array}{c}\text { Keputusa } \\
\text { n } \\
\text { Pembelian } \\
\text { (Y) }\end{array}$ & $\begin{array}{l}\text { Adanya perhatian yang } \\
\text { besar dari pelanggan } \\
\text { terhadap suatu produk, } \\
\text { menunjukkan adanya } \\
\text { pemusatan perhatian } \\
\text { dan perasaan senang, } \\
\text { dorongan untuk ingin } \\
\text { memiliki, adanya } \\
\text { perasaan percaya diri } \\
\text { individu terhadap } \\
\text { kualitas, daya guna dan } \\
\text { keuntungan dari produk } \\
\text { yang akan dibeli. } \\
\text { Kotler (2010.251) }\end{array}$ & 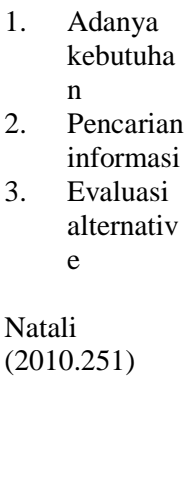 \\
\hline
\end{tabular}

Sumber : Data Olahan

\section{Metode Analisis Data}

Metode yang digunakan untuk mengolah dan menganalisa data untuk mendapatkan hasil penelitian. Metode analisis data yang digunakan dalam penelitian ini ialah analisis regresi linier berganda.

\section{Uji Validitas}

Dalam mengukur validitas keabsahan butir instrumen atau keabsahan internal instrumen, dilkukan dengan cara menganalisis hubungan antara skor tiap butir dan skor total. Perhitungan tersebut menghasilkan butir yang valid dan yang tidak valid. Kriteria yang digunakan untuk uji coba keabsahan butir instrumen adalah $r$ hitung pada $\alpha=0.05$. (Santoso, 2012:43).

- Jika $r$ hitung > $r$ tabel, maka butir pernyataan dinggap valid

- Jika $\mathrm{r}$ hitung < $\mathrm{r}$ tabel, maka pernyataan dianggap tidak valid

\section{Uji Reliabilitas}

Proses pengukuran terhadap ketepatan (konsisten) dari suatu instrumen. Pengujian ini dimaksud untuk menjamin instrumen yang digunakan merupakan sebuah instrumen yang handal, konsistensi, stabil dan dependibilitas, sehingga bila digunakan berkali - kali dapat menghasilkan data yang sama.

Pengukuran reliabilitas yang dilakukan pada penelitian ini dengan menggunakan cara one shot. Disini pengukurannya hanya sekali saja dan kemudian hasilnya dibandingkan dengan pertanyaan lain atau mengukur korelasi atara jawaban pertanyaan. Suatu konstruk atau variabel dikatakan reliabel jika memberikan nilai Cronbach Alpha > 0,60 (Ghozali, 2007)

\section{Regresi Linear Berganda}

Selanjutnya untuk melakukan analisis regresi linear berganda dengan menggunakan model sebagai berikut :

$$
\begin{array}{ll}
\mathbf{Y}=\mathbf{a}+ & \mathbf{b} 1 \mathbf{X}_{\mathbf{1}}+\mathbf{b} \mathbf{2} \mathbf{X}_{\mathbf{2}} \\
\mathrm{Y} & =\text { Keputusan Pembelian } \\
\mathrm{a} & =\text { Konstanta } \\
\mathrm{b}_{1}, \mathrm{~b}_{2} & =\text { Koefisien Regresi } \\
\mathrm{X}_{1} & =\text { Produk } \\
\mathrm{X}_{2} & =\text { Harga }
\end{array}
$$


HASIL DAN PEMBAHASAN Analisis Deskripsi Variabel

Variabel-variabel yang akan dianalisis meliputi Produk $\left(\mathrm{X}_{1}\right)$, Harga $\left(\mathrm{X}_{2}\right)$, dan Keputusan Pembelian (Y). Dalam penelitian ini masing-masing variabel memiliki indikator yang akan dianalisis. Dari pernyataan pada kuesioner diperoleh berbagai macam tanggapan yang diolah dan diberikan kategori sesuai dengan kriteria.

\section{Produk}

Produk merupakan salah satu alat positioning utama dalam pemasaran yang mempunyai dampak langsung pada kinerja produk serta terhubung dekat dengan nilai dan kepuasaan pelanggan. Indikator produk adalah Kualitas produk, Ukuran produk, dan Desain produk

Rekapitulasi

tanggapan

responden tentang produk digambarkan melalui distribusi data yang dapat dilihat pada tabel 5 berikut:

Tabel 5. Rekapitulasi Tanggapan tentang Produk

\begin{tabular}{cccc}
\hline No & Indikator & $\begin{array}{c}\text { Rata- } \\
\text { rata }\end{array}$ & Kategori \\
\hline $\mathbf{1}$ & Kualitas produk & 3.34 & Cukup Baik \\
$\mathbf{2}$ & Ukuran produk & 3.35 & Cukup Baik \\
$\mathbf{3}$ & Desain produk & 3.31 & Cukup Baik \\
& Rata-rata & $\mathbf{3 . 3 3}$ & Cukup Baik \\
\hline
\end{tabular}

Sumber: Data Olahan

Harga

Harga secara luas didefinisikan sebagai jumlah nilai yang ditukarkan konsumen untuk keuntungan memiliki dan menggunakan produk atau jasa yang memungkinkan perusahaan mendapatkan laba yang wajar dengan cara dibayar untuk nilai pelanggan yang diciptakannya. Indikator harga adalah penetapan harga, elastisitas harga dan pertumbuhan harga

Rekapitulasi tanggapan jawaban responden tentang harga digambarkan melalui distribusi data yang dapat dilihat pada tabel 6 berikut:
Tabel 6. Rekapitulasi Tanggapan tentang Harga

\begin{tabular}{clcc}
\hline No & \multicolumn{1}{c}{ Indikator } & Rata rata & Kategori \\
\hline $\mathbf{1}$ & Penetapan Harga & 3.33 & Cukup Baik \\
$\mathbf{2}$ & Elastisitas Harga & 3.28 & Cukup Baik \\
$\mathbf{3}$ & Pertumbuhan & 3.32 & Cukup Baik \\
& Harga & & \\
& Rata-rata & $\mathbf{3 . 3 1}$ & $\begin{array}{c}\text { Cukup } \\
\text { Baik }\end{array}$ \\
\hline
\end{tabular}

Sumber: Data Olahan

Keputusan Pembelian

Keputusan Pembelian adalah adanya perhatian yang besar dari pelanggan terhadap suatu produk yang akan dibelinya, menunjukkan adanya pemusatan perhatian dan perasaan senang, dorongan untuk memiliki, adanya perasaan percaya diri terhadap kualitas, daya guna dan keuntungan produk. Indikator variabel keputusan pembelian adalah adanya kebutuhan, pencarian informasi sebelum pembelian, dan evaluasi alternatif

Rekapitulasi tanggapan jawaban responden tentang keputusan pembelian digambarkan melalui distribusi data yang dapat dilihat pada tabel 5 berikut:

Tabel 7. Rekapitulasi Tanggapan Keputusan Pembelian

\begin{tabular}{clcc}
\hline No & \multicolumn{1}{c}{ Indikator } & $\begin{array}{c}\text { Rata- } \\
\text { rata }\end{array}$ & Kategori \\
\hline $\mathbf{1}$ & Adanya kebutuhan & 3.33 & Cukup Baik \\
$\mathbf{2}$ & $\begin{array}{l}\text { Pencarian } \\
\text { Informasi }\end{array}$ & 3.35 & Cukup Baik \\
$\mathbf{3}$ & $\begin{array}{l}\text { Evaluasi } \\
\text { alternative }\end{array}$ & 3.32 & Cukup Baik \\
& $\quad$ Rata-rata & $\mathbf{3 . 3 3}$ & Cukup Baik \\
\hline
\end{tabular}

Sumber: Data Olahan

Uji Validitas

Menurut Umar (2008), untuk melakukan uji validitas instrumen dengan melakukan uji coba pengukur pada sejumlah responden, responden diminta untuk menjawab pertanyaanpertanyaan yang ada. Jika nilai Corrected Item Total Corelation setiap pertanyaan lebih besar dari 0,30 maka butir pertanyaan dianggap valid. 
Tabel 8. Hasil uji Validitas Produk $\left(\mathbf{X}_{1}\right)$

\begin{tabular}{cccc}
\hline No. & r hitung & r tabel & Keterangan \\
\hline $\mathbf{1}$ & 0.379 & 0.300 & Valid \\
$\mathbf{2}$ & 0.327 & 0.300 & Valid \\
$\mathbf{3}$ & 0.381 & 0.300 & Valid \\
$\mathbf{4}$ & 0.370 & 0.300 & Valid \\
$\mathbf{5}$ & 0.397 & 0.300 & Valid \\
$\mathbf{6}$ & 0.611 & 0.300 & Valid \\
$\mathbf{7}$ & 0.383 & 0.300 & Valid \\
$\mathbf{8}$ & 0.458 & 0.300 & Valid \\
$\mathbf{9}$ & 0.393 & 0.300 & Valid \\
$\mathbf{1 0}$ & 0.409 & 0.300 & Valid \\
$\mathbf{1 1}$ & 0.394 & 0.300 & Valid \\
$\mathbf{1 2}$ & 0.470 & 0.300 & Valid \\
$\mathbf{1 3}$ & 0.416 & 0.300 & Valid \\
$\mathbf{1 4}$ & 0.397 & 0.300 & Valid \\
$\mathbf{1 5}$ & 0.382 & 0.300 & Valid \\
\hline Sumber: Data Olahan SPSS, 2018 &
\end{tabular}

Tabel 9. Hasil uji Validitas Harga $\left(X_{2}\right)$

\begin{tabular}{cccc}
\hline No & r hitung & r table & $\begin{array}{l}\text { Keteranga } \\
\text { n }\end{array}$ \\
\hline $\mathbf{1}$ & 0.459 & 0.300 & Valid \\
$\mathbf{2}$ & 0.507 & 0.300 & Valid \\
$\mathbf{3}$ & 0.369 & 0.300 & Valid \\
$\mathbf{4}$ & 0.326 & 0.300 & Valid \\
$\mathbf{5}$ & 0.374 & 0.300 & Valid \\
$\mathbf{6}$ & 0.424 & 0.300 & Valid \\
$\mathbf{7}$ & 0.513 & 0.300 & Valid \\
$\mathbf{8}$ & 0.496 & 0.300 & Valid \\
$\mathbf{9}$ & 0.637 & 0.300 & Valid \\
$\mathbf{1 0}$ & 0.445 & 0.300 & Valid \\
$\mathbf{1 1}$ & 0.335 & 0.300 & Valid \\
$\mathbf{1 2}$ & 0.329 & 0.300 & Valid \\
$\mathbf{1 3}$ & 0.421 & 0.300 & Valid \\
$\mathbf{1 4}$ & 0.371 & 0.300 & Valid \\
$\mathbf{1 5}$ & 0.314 & 0.300 & Valid \\
\hline \multicolumn{5}{|l}{ Tumber: Data Olahan SPSS, 2018} &
\end{tabular}

Tabel 10 Hasil uji Validitas Keputusan Pembelian (Y)

\begin{tabular}{cccc}
\hline No & r hitung & r tabel & Keterangan \\
\hline $\mathbf{1}$ & 0.390 & 0.300 & Valid \\
$\mathbf{2}$ & 0.335 & 0.300 & Valid \\
$\mathbf{3}$ & 0.417 & 0.300 & Valid \\
$\mathbf{4}$ & 0.354 & 0.300 & Valid \\
$\mathbf{5}$ & 0.402 & 0.300 & Valid \\
$\mathbf{6}$ & 0.438 & 0.300 & Valid \\
$\mathbf{7}$ & 0.387 & 0.300 & Valid \\
$\mathbf{8}$ & 0.431 & 0.300 & Valid \\
$\mathbf{9}$ & 0.372 & 0.300 & Valid \\
$\mathbf{1 0}$ & 0.363 & 0.300 & Valid \\
$\mathbf{1 1}$ & 0.434 & 0.300 & Valid \\
$\mathbf{1 2}$ & 0.411 & 0.300 & Valid \\
$\mathbf{1 3}$ & 0.420 & 0.300 & Valid \\
$\mathbf{1 4}$ & 0.367 & 0.300 & Valid \\
$\mathbf{1 5}$ & 0.327 & 0.300 & Valid \\
\hline \multicolumn{5}{l}{ Sumber: Data Olahan SPSS, 2018 }
\end{tabular}

\section{Uji Reliabilitas}

Pengukuran reliabilitas yang dilakukan pada penelitian ini dengan menggunakan cara one shot. Disini pengukurannya hanya sekali saja dan kemudian hasilnya dibandingkan dengan pertanyaan lain atau mengukur korelasi atara jawaban pertanyaan. Suatu konstruk atau variabel dikatakan reliabel jika memberikan nilai Cronbach Alpha > 0,60 (Ghozali, 2007)

Tabel 11 Hasil uji Reliabilitas

\begin{tabular}{lcc}
\hline Variabel & $\begin{array}{c}\text { Cronbach } \\
\text { Alpha }\end{array}$ & Ket. \\
\hline Produk $\left(\mathrm{X}_{1}\right)$ & 0,802 & Reliabel \\
\hline Harga $\left(\mathrm{X}_{2}\right)$ & 0,801 & Reliabel \\
\hline $\begin{array}{l}\text { Keputusan } \\
\text { Pembelian (Y) }\end{array}$ & 0,784 & Reliabel \\
\hline Sumber: Data Olahan SPSS, 2018 &
\end{tabular}

Analisis Linear Berganda

Untuk menguji pengaruh variabel independen yaitu produk $\left(\mathrm{X}_{1}\right)$ dan harga $\left(X_{2}\right)$ terhadap keputusan pembelian (Y) dapat dilihat dari analisis regresi linear berganda sebagai berikut:

\begin{tabular}{|c|c|c|c|c|c|}
\hline \multirow[t]{2}{*}{ Model } & \multicolumn{2}{|c|}{$\begin{array}{l}\text { Unstandardized } \\
\text { Coefficients }\end{array}$} & \multirow{2}{*}{$\begin{array}{c}\text { Standardi } \\
\text { zed } \\
\text { Coefficie } \\
\text { nts } \\
\text { Beta }\end{array}$} & \multirow[t]{2}{*}{$\mathrm{T}$} & \multirow[t]{2}{*}{ Sig. } \\
\hline & B & $\begin{array}{l}\text { Std. } \\
\text { Error }\end{array}$ & & & \\
\hline (Constant) & 14.844 & 5.581 & & 2.660 & .010 \\
\hline X1 (produk) & .458 & .095 & .518 & 4.812 & .000 \\
\hline X2 (harga) & .248 & .104 & .256 & 2.382 & .021 \\
\hline
\end{tabular}

Berdasarkan hasil perhitungan diatas diperoleh persamaan regresi linear berganda sebagai berikut:

$\mathrm{Y}=14.844+0.458 \mathrm{X}_{1}+0.248 \mathrm{X}_{2}$

Dari persamaan diatas dapat dijelaskan:

1. Nilai Konstanta (a) 14.844. Artinya apabila variabel independen produk dan harga diasumsikan nol (0) maka keputusan pembelian bernilai sebesar 14.844 .

2. Nilai koefisien regresi variabel produk sebesar 0.458. Artinya adalah setiap peningkatan produk sebesar 1 satuan maka akan 
meningkatkan keputusan pembelian sebesar 0.458 dengan asumsi variabel lain tetap.

3. Nilai koefisien regresi variabel harga sebesar 0.248. Artinya adalah setiap peningkatan harga sebesar 1 satuan maka akan meningkatkan keputusan pembelian sebesar 0.248 dengan asumsi variabel lain tetap.

\section{Uji Model (Uji F)}

Uji $F$ pada dasarnya menunjukkan apakah semua variabel independen yang dimasukkan dalam model mempunyai pengaruh secara bersama-sama terhadap variabel dependennya. Hasil perhitungan Uji $\mathrm{F}$ ini dapat dilihat pada tabel 13 berikut :

\section{Tabel 13 Hasil Pengujian Uji F}

\begin{tabular}{lccccc}
\hline Model & $\begin{array}{l}\text { Sum of } \\
\text { Squares }\end{array}$ & df & $\begin{array}{c}\text { Mean } \\
\text { Square }\end{array}$ & F & Sig. \\
\hline $\begin{array}{l}\text { Regress } \\
\text { ion }\end{array}$ & 1152.504 & 2 & 576.252 & 21.978 & $.000^{\mathrm{b}}$ \\
\hline $\begin{array}{l}\text { Residua } \\
1\end{array}$ & 1494.479 & 57 & 26.219 & & \\
\hline Total & 2646.983 & 59 & & & \\
\hline Sumber: Data Olahan SPSS, 2018
\end{tabular}

didapatkan hasil perhitungan bahwa nilai $F_{\text {hitung }}=21.978$ dan $F_{\text {tabel }}=3,09$ sehingga $F_{\text {hitung }}>$ dari $F_{\text {tabel }}$ dan nilai signifikansi $F_{\text {hitung adalah }}<\alpha 0,05$. Keputusan yang diambil adalah diterimanya hipotesis alternatif menunjukkan variabel bebas yang terdiri dari produk $\left(\mathrm{X}_{1}\right)$ dan harga $\left(\mathrm{X}_{2}\right)$ mampu menjelaskan keragaman dari variabel terikat yaitu keputusan pembelian atau dengan kata lain harga $\left(\mathrm{X}_{1}\right)$, dan produk $\left(\mathrm{X}_{2}\right)$ secara simultan atau bersama-sama berpengaruh signifikan terhadap keputusan pembelian (Y).

\section{Koefisien Determinasi $\left(\mathbf{R}^{\mathbf{2}}\right)$}

Koefisien determinasi bertujuan untuk menunjukan besarnya derajat hubungan antara produk dan harga terhadap keputusan pembelian.

Tabel 14. Hasil Pengujian Koefisien Determinasi

\begin{tabular}{ccccr}
\hline Model & $\mathrm{R}$ & $\begin{array}{c}\mathrm{R} \\
\text { Square }\end{array}$ & $\begin{array}{c}\text { Adjusted } \\
\text { R Square }\end{array}$ & $\begin{array}{c}\text { Std. Error } \\
\text { of the } \\
\text { Estimate }\end{array}$ \\
\hline 1 & $.660^{\mathrm{a}}$ & .435 & .416 & 5.120
\end{tabular}

Sumber: Data Olahan SPSS, 2018

Berdasarkan Tabel 5.14 dapat diketahui bahwa produk dan harga mempunyai hubungan yang kuat dengan keputusan pembelian. Hal ini dapat dibuktikan dengan nilai koefisien Determinasi $\left(\mathrm{R}^{2}\right)$ sebesar 0,416. Hal ini menunjukkan bahwa variabel bebas secara bersama-sama memberikan pengaruh terhadap keputusan pembelian tepung bumbu Mamasuka sebesar 41,6\%. Artinya variabel produk dan harga mempengaruhi keputusan pembelian tepung bumbu Mamasuka sebesar 41,6\%, sedangkan sisanya sebesar 58,4\% dipengaruhi oleh variabel lain yang tidak diamati dalam penelitian ini.

\section{Uji Hipotesis (Uji t)}

Pengujian ini dilakukan untuk mengetahui apakah variabel independen yaitu produk $\left(\mathrm{X}_{1}\right)$, dan harga $\left(\mathrm{X}_{2}\right)$ secara masing-masing mempengaruhi variabel dependen yaitu keputusan pembelian (Y) tepung bumbu mamasuka PT Jico Agung. Pengujian dilakukan dengan menggunakan uji $\mathrm{t}$ atau $t_{\text {hitung. Untuk itu perlu diadakan }}$ perbandingan antara $t_{\text {hitung }}$ dengan $t_{\text {tabel }}$. Dalam penelitian ini digunakan tingkat signifikansi $\alpha=5 \%$ yang artinya kemungkinan kesalahan yang ditolerir adalah 5\%.

Tabel 15. Uji Hipotesis (Uji t)

\begin{tabular}{lccc}
\hline \multicolumn{1}{c}{ Variabel } & T-Hitung & T-Tabel & Sig \\
\hline Produk $\left(\mathbf{X}_{\mathbf{1}}\right)$ & 4.812 & 2.002 & 0.000 \\
Harga $\left(\mathbf{X}_{\mathbf{2}}\right)$ & 2.382 & 2.002 & 0.021 \\
\hline Sumber: Data Olahan SPSS, 2018
\end{tabular}

Dari tabel 15, hasil pengujian secara parsial dapat dijelaskan sebagai berikut: 


\section{Pengaruh Produk Terhadap Keputusan Pembelian}

Pengujian ini bertujuan untuk mengetahui apakah variabel produk berpengaruh secara signifikan atau tidak terhadap keputusan pembelian.

$\mathrm{H}_{0}: \mathrm{b} 1=0, \quad$ artinya tidak terdapat pengaruh antara variabel produk terhadap keputusan pembelian.

$\mathrm{H}_{1}$ : $\mathrm{b} 1 \neq 0$, artinya terdapat pengaruh antara variabel produk terhadap keputusan pembelian

Dari tabel 12 diatas diketahui bahwa produk memiliki t hitung sebesar 4.812 sedangkan $t$ tabel sebesar 2.002 sehingga $t$ hitung $>\mathrm{t}$ tabel dengan nilai signifikansi untuk variabel produk sebesar 0.000lebih kecil dari taraf signifikansi 0.05 . maka $\mathrm{H}_{0}$ ditolak dan $\mathrm{H}_{1}$ diterima, sehingga dapat disimpulkan bahwa secara parsial variabel produk berpengaruh signifikan terhadap keputusan pembelian.

\section{Pengaruh Harga Terhadap Keputusan Pembelian}

Pengujian ini bertujuan untuk mengetahui apakah variabel harga berpengaruh secara signifikan atau tidak terhadap keputusan pembelian.

$\mathrm{H}_{0}: \mathrm{b} 2=0, \quad$ artinya tidak terdapat pengaruh antara variabel harga terhadap keputusan pembelian.

$\mathrm{H}_{1}$ : $\mathrm{b} 2 \neq 0$, artinya terdapat pengaruh antara variabel produk terhadap keputusan pembelian

Dari tabel 12 diatas diketahui bahwa produk memiliki thitung sebesar 2.382 sedangkan $t$ tabel sebesar 2.002 sehingga $t$ hitung $>t$ tabel dengan nilai signifikansi untuk variabel produk sebesar 0.000 lebih kecil dari taraf signifikansi 0.05. maka $\mathrm{H}_{0}$ ditolak dan $\mathrm{H}_{1}$ diterima, sehingga dapat disimpulkan bahwa secara parsial variabel harga juga berpengaruh signifikan terhadap keputusan pembelian.

\section{Pengaruh Produk Terhadap Keputusan Pembelian}

Berdasarkan hasil penelitian diperoleh hasil bahwa produk berpengaruh secara signifikan terhadap keputusan pembelian. Artinya semakin tinggi kualitas produk maka keputusan pembelian mengalami peningkatan. Hasil penelitian ini sejalan dengan yang dilakukan oleh Elvira (2010) dari hasil penelitian menunjukan bahwa terdapat pengaruh antara produk terhadap keputusan pembelian.

\section{Pengaruh Harga Terhadap Keputusan Pembelian}

Berdasarkan hasil penelitian diperoleh hasil bahwa harga berpengaruh secara signifikan terhadap keputusan pembelian. Artinya semakin tinggi harga maka keputusan pembelian mengalami penurunan. Hasil penelitian ini sejalan dengan yang dilakukan oleh Erni (2016) dari hasil penelitian menunjukan bahwa terdapat pengaruh antara harga terhadap keputusan pembelian.

\section{PENUTUP \\ Kesimpulan}

Berdasarkan hasil analisis dan pembahasan yang telah diuraikan pada bab sebelumnya, maka diperoleh hasil bahwa produk dan harga secara simultan atau bersama-sama memiliki pengaruh signifikan terhadap keputusan pembelian. Dan secara parsial atau masing-masing produk dan harga juga memiliki pengaruh signifikan terhadap keputusan pembelian.

\section{Saran}

PT Jico Agung disarankan untuk meningkatkan kualitas produk dan desain produk serta memberikan harga yang kompetitif untuk meningkatkan minat konsumen ditengah kompetitor yang semakin bertambah. 
DAFTAR PUSTAKA

Assauri. Sofjan. (2010). Menejemen Pemasaran. Rajawali Pers.

Buchari, Alma. (2011). Manajemen Pemasaran dan Pemasaran Jasa. Bandung: Alfabeta.

Erni. (2016). Pengaruh Kualitas Produk dan Harga Terhadap Keputusan Pembelian Sepeda Motor Kawasaki Athlete pada CV Dwi Eka Sakti di Pekanbaru. Skripsi

Hasibuan. Malayu S.P. (2011). MANAJEMEN: Dasar, Pengertian, dan Masalah. Jakarta : PT Aksara

Hasan. (2013). Marketing dan Kasus Kasus Pilihan. Yogyakarta, CAPS (Center For Academic Publishing Service)

Isyanto, Puji. (2012). Pengaruh Kualitas Produk terhadap Keputusan Pembelian Handphone Blackberry pada Mahasiswa Ekonomi Universitas Singaperbangsa Karawang. Jurnal Manajemen, 9 (4), 854862.

Kotler, Philip dan Gary armstrong. (2009). Prinsip-Prinsip Pemasaran, Edisi 12, jilid 2. Jakarta: Erlangga

Kotler, Philip dan Amstrong, Garry. (2010). Prinsip-Prinsip pemasaran, Jilid 1 dan 2 Edisi Kedua Belas. Jakarta: Erlangga.

Kotler, Philip dan Kevin Lane Keller. (2008). Manajemen Pemasaran, Jilid 1. Jakarta: Penerbit Erlangga.

Kotler, dan Amstrong. (2012), Pengaruh Iklan Televisi dan Harga Terhadap keputusan Pembelian Sabun Lux, Jurnal Riset Sains Indonesia. Vol. 3(1)

Kotler dan Keller. (2009). Manajemen Pemasaran. Edisi tigabelas jilid satu. Jakarta: Indeks.
Laksana, Fajar. (2008). Manajemen Pemasasaran : Pendekatan Praktis. Edisi Pertama. Cetakan Pertama. Yogyakarta: Graha Ilmu.

Margiyanto, May. (2013). Analisis Pengaruh Citra Merek, Persepsi Harga, Kualitas Produk, dan Promosi Terhadap Keputusan Pembelian Balckberry di kota Semarang. Skripsi. Universitas Diponegoro. Semarang.

Purwati. (2012). Pengaruh Harga dan Kualitas Produk terhadap Keputusan Pembelian Motor Honda Matic Beat (Studi Kasus Pada PT. Nusantara Solar Sakti). 2(3), 260-277.

Rambat. (2013). Manajemen Pemasaran Jasa. Jakarta: Salemba Empat.

Roza, Arwen Elvina. (2016). Pengaruh Kualitas Produk dan Harga Terhadap Keputusan Pembelian Sepeda Motor Kawasaki Athlete Pada CV Dwi Eka Sakti di pekanbaru.

Swasta, (2008). Manajemen Pemasaran Modern, Yogyakarta: liberty,

Tjiptono. (2008). Strategi Pemasaran, Edisi III. Yogyakarta: Andi Offset

Wangean, Ryanto Hariandy. (2014). Analisis Citra Merek, Kualitas Produk dan Harga.

Wardani, Hetty Sri. (2015). Pengaruh kualitas produk dan harga terhadap minat beli konsumen muslim pada Jaizah Boutique Tlogosari Semarang. Undergraduate (S1) thesis, UIN Walisongo. 